Proceeding Paper

\title{
Diagenesis of the Sedimentary Fe-Ni Deposits of Euboea: Evidence Based on Phyllosilicate Mineralogy ${ }^{\dagger}$
}

\author{
Spyros Cheliotis-Chatzidimitriou ${ }^{1, *}$, Georgios E. Christidis ${ }^{1, *(\mathbb{D})}$ and Ioannis Marantos ${ }^{2}$ \\ 1 School of Mineral Resources Engineering, Technical University of Crete, 73100 Chania, Greece \\ 2 Hellenic Survey of Geology and Mineral Exploration (H.S.G.M.E.), 13677 Acharnae, Greece; \\ yanmarantos@igme.gr \\ * Correspondence: schatzidimitriou@isc.tuc.gr (S.C.-C.); christid@mred.tuc.gr (G.E.C.); \\ Tel.: +30-2821-037-622 (G.E.C.) \\ + Presented at International Conference on Raw Materials and Circular Economy, Athens, Greece, \\ 5-9 September 2021.
}

check for

updates

Citation: Cheliotis-Chatzidimitriou, S.; Christidis, G.E.; Marantos, I. Diagenesis of the Sedimentary Fe-Ni Deposits of Euboea: Evidence Based on Phyllosilicate Mineralogy. Mater. Proc. 2021, 5, 73. https://doi.org/ $10.3390 /$ materproc2021005073

Academic Editor: Anthimos Xenidis

Published: 10 December 2021

Publisher's Note: MDPI stays neutral with regard to jurisdictional claims in published maps and institutional affiliations.

Copyright: (c) 2021 by the authors. Licensee MDPI, Basel, Switzerland. This article is an open access article distributed under the terms and conditions of the Creative Commons Attribution (CC BY) license (https:// creativecommons.org/licenses/by/ $4.0 /)$.

\begin{abstract}
A set of samples with different textures from the sedimentary Fe-Ni deposits of Central Euboea, Greece, were studied with XRD and SEM-EDS to investigate the relationships between phyllosilicates present. The deposits are characterized by the coexistence of smectite, corrensite, R0 mixed-layer chlorite-smectite and discrete chlorite, which indicates disequilibrium conditions. It is suggested that chlorite, the main Ni-host in the deposits, formed by conversion of smectite (nontronite and possibly stevensite), via corrensite and R0 Chl-Sme during diagenesis. This is the first report for chloritization of Fe-rich dioctahedral smectite during diagenesis.
\end{abstract}

Keywords: sedimentary Fe-Ni deposits; mixed layer chlorite-smectite; corrensite; serpentine; smectite; chlorite; diagenesis; Euboea

\section{Introduction}

The sedimentary Fe-Ni deposits in Euboea, central Greece, have been studied extensively over the last 60 years. It is well established that $\mathrm{Ni}$ is hosted mainly in phyllosilicates, including chlorite, talc and "garnierite" [1-6]. Minor Ni-hosts in the Euboea deposits are Fe-oxides/oxyhydroxides (hematite/goethite) and possibly illite [4-6]. In contrast, there are contradictory reports about the presence and significance of smectite in the deposits, although its presence was verified in the Lokris area [7]. In general, it is considered that smectite is either absent [6], or is present as an accessory phase in the form of trioctahedral saponite [3].

Previous studies on the sedimentary Fe-Ni deposits of Lokris and Euboea have shown that the deposits have been affected by post-depositional processes, which resulted in redistribution of certain elements, such as $\mathrm{Ni}$ and $\mathrm{As}[1,8,9]$. Inasmuch as the main hosts of $\mathrm{Ni}$ in the original lateritic mantles are phyllosilicates, mainly Ni-serpentine, Ni-stevensite and Ni-talc [10-12] it is expected that such post-depositional processes should have affected the phyllosilicate mineralogy.

To date, there are only scarce data on the phyllosilicate mineralogy of the Euboean deposits, with most of the studies being focused mainly in the Lokris area [6,7]. In this contribution we report on the phyllosilicate mineralogy of a series of deposits of Central Euboea, and examine its significance on the diagenetic evolution of the deposits.

\section{Materials and Methods}

Twenty-seven samples were collected from the deposits of Katsikiza, Pagondas, Koutos, Platani, Vrysakia and Rekavetsi Central Euboea (Figure 1). The deposits have a well-defined quasi-linear E-W orientation (Figure 1). Fourteen of these samples were collected from the Vrysakia deposit along one vertical and one horizontal profile. The 
remaining samples were collected randomly from the other deposits. The samples were dried overnight at $105{ }^{\circ} \mathrm{C}$ and ground in an agate pestle and mortar to pass through a $63 \mu \mathrm{m}$ sieve. The bulk mineralogical composition of the clinkers was determined by X-ray diffraction (XRD). The samples were examined on a Bruker D8 Advance Diffractometer equipped with a Lynx Eye strip silicon detector, using Ni-filtered $\mathrm{CuK} \alpha$ radiation $(35 \mathrm{kV}$, $35 \mathrm{~mA})$. Data were collected in the range $4-70^{\circ} 2 \theta$ with a step size of $0.02^{\circ}$ and counting time $1 \mathrm{~s}$ per strip step (total time $63.6 \mathrm{~s}$ per step). The XRD traces were analyzed and interpreted with the Diffract Plus software package from Bruker and the Powder Diffraction File (PDF).

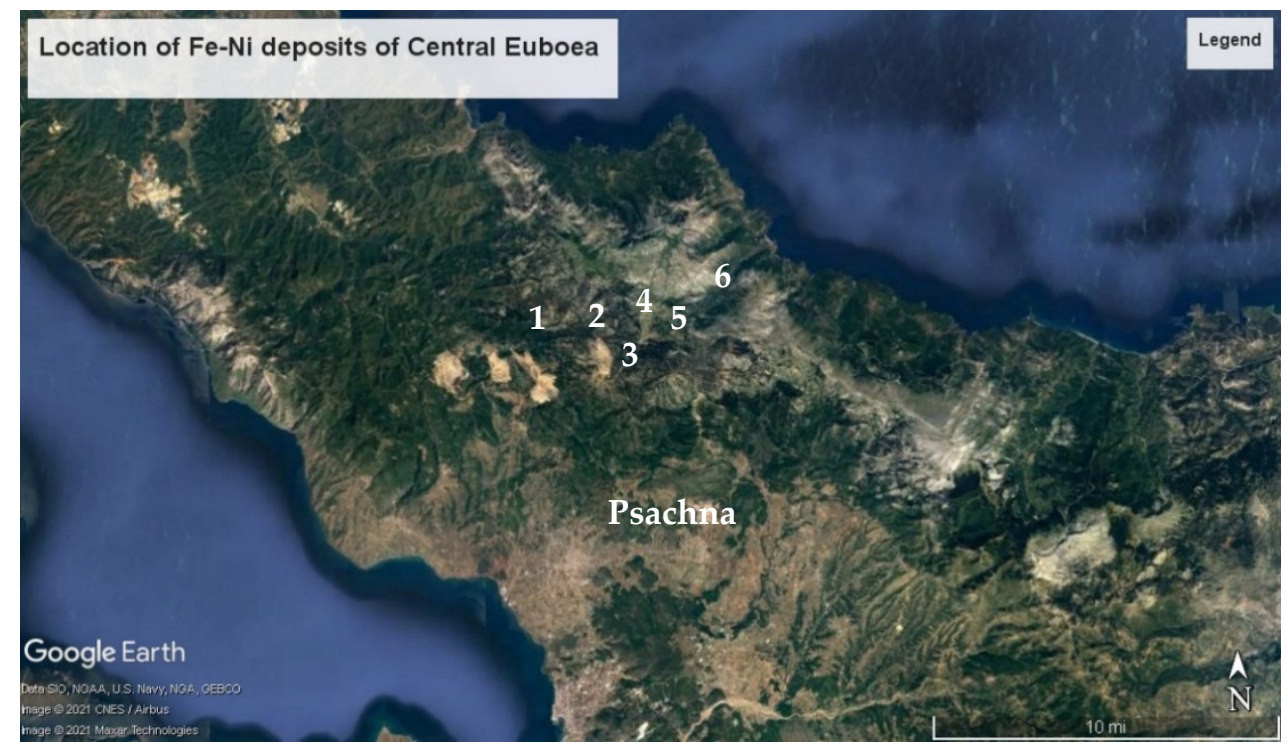

Figure 1. Location of the sedimentary Fe-Ni deposits in Central Euboea. $1=$ Pagontas, $2=$ Rekavetsi, $3=$ Katsikiza, $4=$ Koutos, $5=$ Vrysakia and $6=$ Platani.

The clay mineralogy was determined from sediments dispersed in distilled water using an ultrasonic probe (30 s). The less than $2 \mu \mathrm{m}$ fractions were separated by settling, dried on glass slides at room temperature and then were solvated with ethylene glycol vapor at $60^{\circ} \mathrm{C}$ overnight to ensure maximum saturation. XRD traces of the clay fractions, both air dried (AD) and after ethylene glycol (EG) solvation. Data were collected in the range of $2-35^{\circ} 2 \theta$ with a step size of $0.02^{\circ}$ and counting time $0.5 \mathrm{~s}$ per strip step (total time 31.8 s per step). Complex diffraction maxima were deconvolved into the individual mineral phases with the Ftiyk software [13]. The individual peak components were modeled with the Voigt function after subtraction of the background.

Mineral textures and semiquantitative chemical composition of the clay minerals were determined with scanning electron microscopy (SEM) using a JEOL 5600 SEM equipped with an energy dispersive spectrometer (EDS, Oxford Instruments, Abingdon, UK), at the Department of Geology and Geoenvironment, National and Kapodistrian University of Athens, Greece. The analyses were performed on polished blocks using back-scattered electron (BSE) images.

\section{Results}

\subsection{Mineral Textures and Bulk Mineralogy of the Fe-Ni Ores}

The deposits are characterized both by pisolitic and pelitic textures. They consist of complex (peloids, scarce pisoids) and individual grains of hematite with variable sphericity (angular to rounded) as basic components, embedded in a groundmass consisting of clay minerals and Fe-oxides/oxyhydroxides (Figure 2). They also contain angular to rounded quartz and calcite, goethite, accessory chromite fragments and trace pyrite. The texture of the main phases indicates limited transportation from the sources. The bulk phyllosilicate mineralogy is comparable in all deposits, regardless of the ore texture. The main phases 
are a $14 \AA$ phase with a broad diffraction maximum centered at $\sim 6^{\circ} 2 \theta$. A second weaker maximum occurs at $\sim 12.5^{\circ} 2 \theta$. These features are indicative of a chlorite-bearing phase. Talc (kerolite-pimelite) is minor phase in all deposits, being a major phase in sectors of the Vrysakia deposit. Smectite was identified as major phase in sectors of the Vrysakia, Koutos and Rekavetsi deposits, and discrete illite in the Vrysakia deposit. The $\mathrm{d}_{060}$ of smectite varies between 1.506 and 1.513, suggesting a Fe-rich dioctahedral variety similar to the smectite in Lokris [7]. In contrast, serpentine is scarcely present in the deposits.

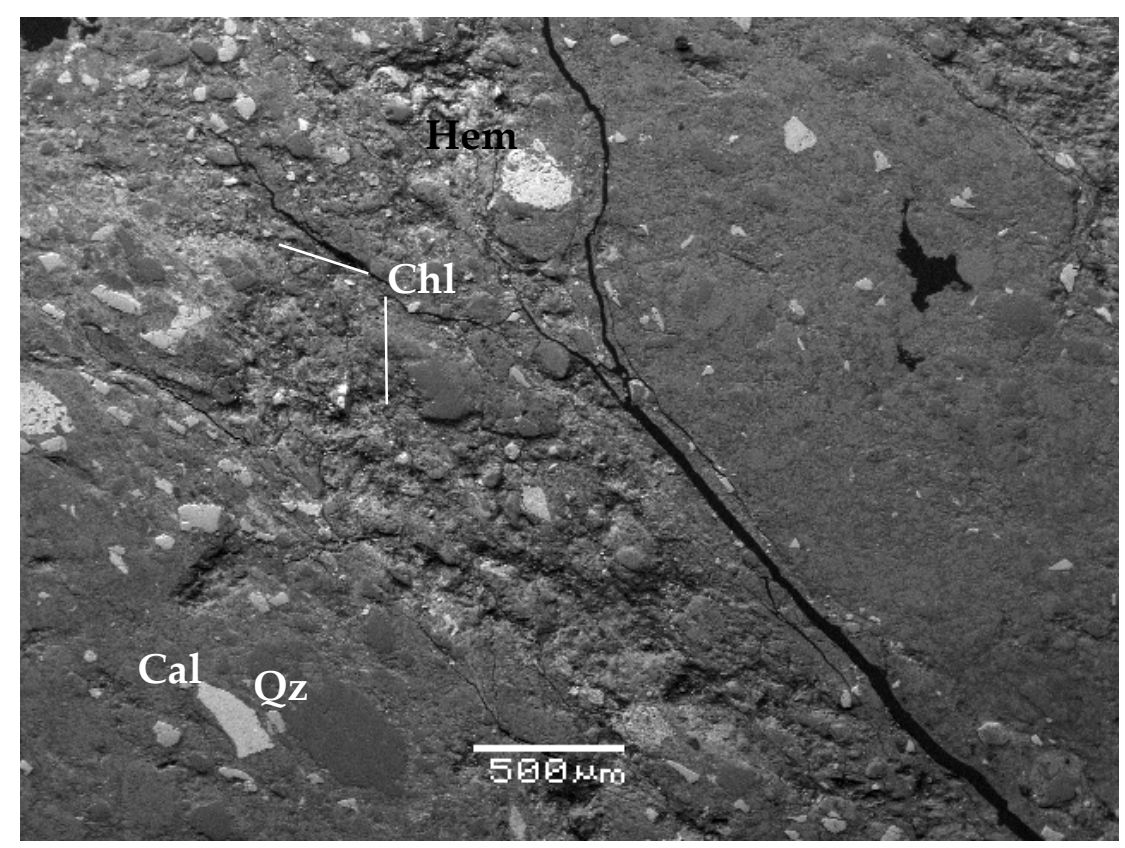

Figure 2. SEM micrograph of a sample from the Vrysakia sedimentary Fe-Ni deposit. Chl = chlorite, Hem $=$ hematite, $\mathrm{Cal}=$ calcite, $\mathrm{Qz}=$ quartz. The mineral symbols are named from Warr $[14,15]$.

\subsection{Clay Mineralogy}

The air-dried clay fractions show the predominance of a 14/7 $\AA$ phase and talc (Tlc) (Figure 3). In some sectors of the Vrysakia section and the Platani deposit, abundant corrensite (Crr) is also present (Figure 4). The Rekavetsi and Koutos deposits contain sectors with abundant discrete smectite. After EG-solvation the diffraction maximum at $14 \AA$ is analyzed in three components at $17 \AA, 15.3 \AA$ and $14.2 \AA$, which correspond to smectite (Sme), R0 mixed layer chlorite-smectite (Chl-Sme) and discrete chlorite (Chl), respectively (Figures 3 and 4). Similarly, the diffraction maximum at $7 \AA$ is analyzed in two components, corresponding to R0 mixed layer chlorite-smectite and discrete chlorite. In some samples the diffraction maximum centered at $15.3 \AA$ includes also a corrensite component (Figure 4). Certain sections of the Vrysakia deposit are dominated by talc layers (Figure $3 b)$. The mineral symbols are named from Warr [14,15]. 


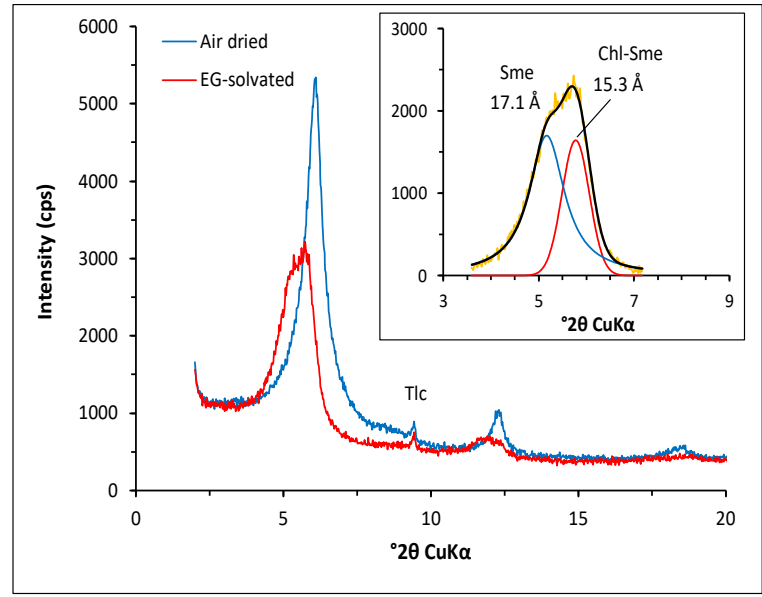

(a)

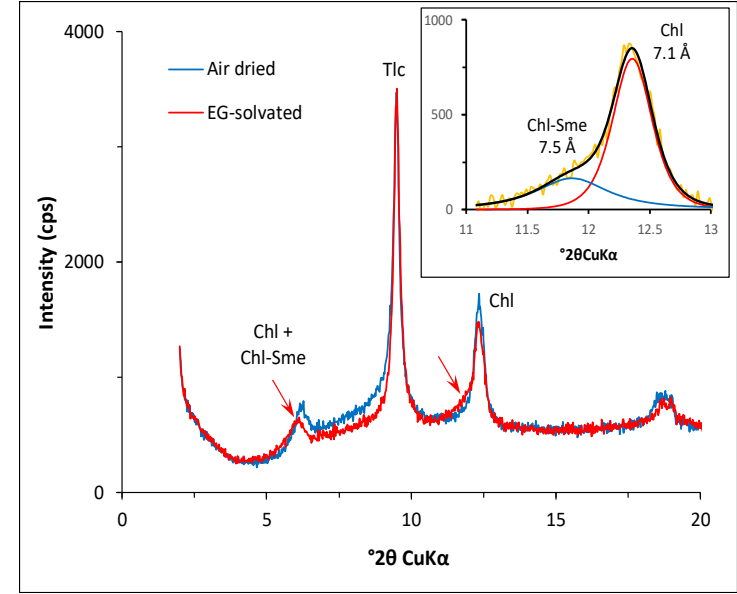

(b)

Figure 3. XRD traces of representative samples of oriented $-2 \mu \mathrm{m}$ clay fractions from the Vrysakia deposit. (a) Coexistence of abundant smectite (Sme) and R0 mixed-layer chlorite-smectite (Chl-Sme), (b) coexistence of talc (Tlc) with R0 Chl-Sme and discrete chlorite (Chl). The mineral symbols are named from Warr [14].

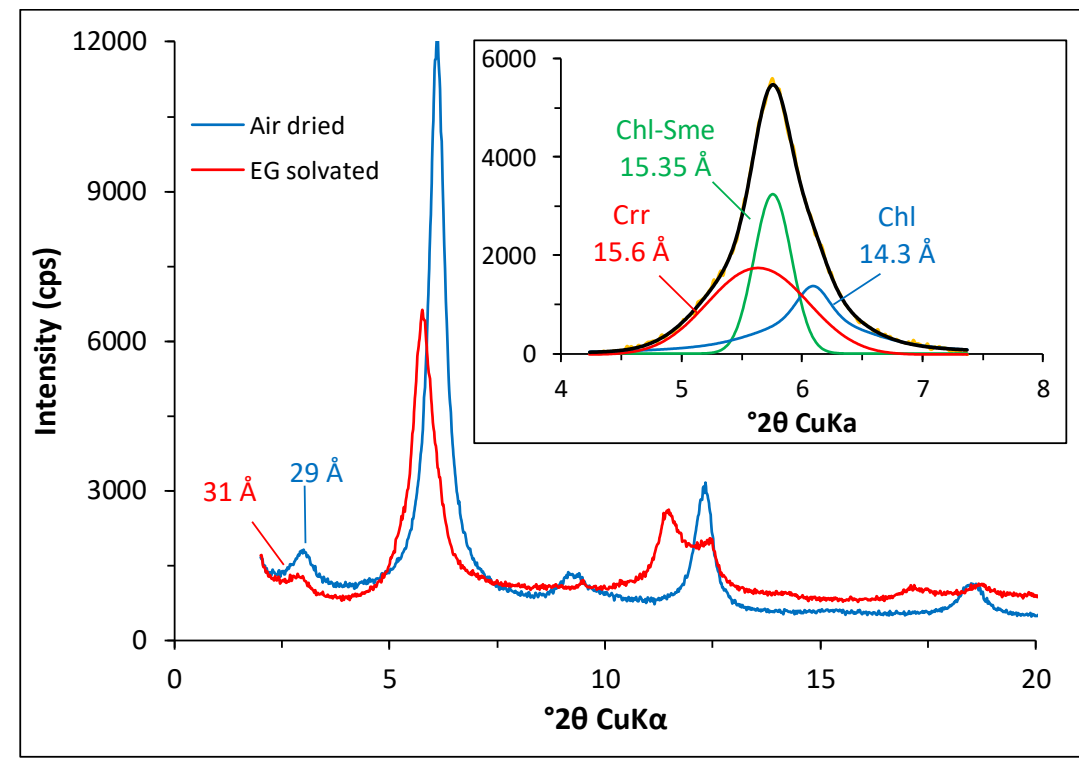

Figure 4. XRD traces of representative samples of oriented $-2 \mu \mathrm{m}$ clay fractions from the Vrysakia deposit with coexisting corrensite (Crr, R1 mixed layer Chl-Sme), R0 mixed layer Chl-Sme and distinct chl. The mineral symbols are named from Warr [14]. See text for discussion.

\section{Discussion}

The clay mineralogical investigation of the sedimentary Fe-Ni deposits of Central Euboea showed that the clay fractions consist of a variety of clay minerals, including discrete and mixed layer phases, both with ordered and random interstratification. Furthermore, several deposits contain abundant smectite (Figure 3a), indicating that smectite is a major clay mineral phase at least in some deposits. This is in accordance with previous reports on the Agios Ioannis Fe-Ni deposit in Lokris, which contains abundant smectite [7]. Although it was not possible to identify the exact type of smectite, the $\mathrm{d}_{060}$ value and the similarities with the Agios Ioannis deposit point towards a nontronitic (i.e., Fe-rich) composition. Such a composition is expected when considering the source rocks of the materials.

The coexistence of discrete smectite and chlorite, with corrensite and R0 Chl-Sme strongly suggests that (a) diagenetic reactions have affected the original clay mineral composition of the deposits and (b) diagenesis proceeds with conversion of smectite to chlorite. The conversion mechanism of smectite to chlorite via corrensite and mixed layer 
R0 Chl-Sme and/or mixed layer Crr-Chl has been reported in the past in diagenetic, metamorphic, and hydrothermal environments [16-21]. The main problem in the interpretation of smectite chloritization in this study is that, to date, transformation of nontronite (Non) has not been reported in the literature. Indeed, chloritization has been reported to occur via conversion of (a) saponite to Mg-chlorite via corrensite and mixed layer Crr-Chl [16-18,20], (b) bertherine to chlorite via mixed layer bertherine-chamosite [19] in Fe-rich systems, or (c) kaolinite to sudoite via tosudite in Al-Mg-rich systems [21].

Semiquantitative analyses of chlorites by ED-SEM (data not shown) and from previous work in the area [4,5] have shown that chlorite is the main host of $\mathrm{Ni}$ in the deposits; additionally, it contains abundant $\mathrm{MgO}$ and $\mathrm{FeO}$, i.e., it is not Fe-rich (chamosite). Moreover, the deposits contain only traces of serpentine (Srp), although it is expected that the original weathered lateritic mantles contained abundant serpentine, possibly Ni-rich, as it is the case in the laterites s.s of the Kastoria area Greece [5] and New Caledonia [12]. It is suggested that the main source of $\mathrm{Mg}$ and $\mathrm{Ni}$ in chlorite is the dissolution of serpentine and the main source of $\mathrm{Fe}$ is the dissolution of nontronite during diagenesis. An additional source of $\mathrm{Mg}$ and Ni might have been the dissolution of Ni-stevensite (Stv) which, after its first identification in the Othrys mountain, Greece [10], has been reported as a main phase in laterites in Brazil and N. Caledonia [11,12]. The formation of abundant talc layers in sectors of the Vrysakia deposit may also be ascribed to transformation of stevensite during diagenesis. Therefore, the main reaction path for chlorite formation in the deposits can be described as follows:

$$
\mathrm{Nnt}+\mathrm{Stv}+\mathrm{Srp} \rightarrow \mathrm{Crr} \rightarrow \mathrm{R} 0 \mathrm{Chl}-\mathrm{Smec} \rightarrow \mathrm{Chl}
$$

The coexistence of smectite, corrensite, R0 mixed layer Chl-Sme and discrete chlorite suggests that the system may not be at equilibrium. Furthermore, the predominance of mixed layer Chl-Sme and the presence of discrete chlorite in the paragenesis, indicate that the burial temperature might have been $70-100{ }^{\circ} \mathrm{C}$. Nevertheless, additional work would be necessary for more accurate estimation of burial conditions and confirmation of Equation (1).

Finally, since both stevensite and serpentine would have been important Ni-sources in the original lateritic mantle, the diagenetic process described by Equation (1) might explain the observed mobilization of $\mathrm{Ni}$ in the deposits, described by previous workers [1]. What remains to be verified, is whether such a reaction path would be associated with mobilization of critical metals such as Co, present in the deposits. This is because Co is also hosted in stevensite during lateritization [10].

\section{Conclusions}

The sedimentary Fe-Ni deposits of Central Euboea that were formed from the erosion of lateritic mantles contain a variety of phyllosilicates, which are indicative of certain diagenetic reactions. The main characteristic of the deposits is the coexistence of smectite with corrensite, R0 mixed layer Chl-Sme and discrete chlorite, which suggest disequilibrium conditions. It is suggested that chlorite, the main Ni-host in the deposits, is diagenetic, formed by a gradual conversion of Fe-rich smectite and possibly stevensite. This alteration might be associated with mobilization of $\mathrm{Ni}$ and $\mathrm{Co}$ during diagenesis. Additional work would be necessary to specify the exact reaction paths between phyllosilicates and to investigate the mobilization of $\mathrm{Ni}$ and critical metals during diagenesis.

Author Contributions: S.C.-C., methodology, investigation, data interpretation writing-review and editing; G.E.C., conceptualization, supervision, data interpretation writing-review and editing; I.M., data interpretation writing-review and editing. All authors have read and agreed to the published version of the manuscript.

Funding: This research received no external funding.

Institutional Review Board Statement: Not applicable. The study did not involve humans or animals. 


\section{Informed Consent Statement: Not applicable.}

Acknowledgments: We would like to thank LARCO GMMSA for allowing us to sample the deposits and the geologists of the company for helping in sampling. We are indebted to Stephen Kilias and Vas. Skounakis for their permission and assistance with the SEM analysis, and A. Stratakis for the XRD analysis.

Conflicts of Interest: The authors declare no conflict of interest.

\section{References}

1. Valeton, I.; Biermann, M.; Reche, R.; Rozenberg, F. Genesis of nickel laterites and bauxites in Greece during the Jurassic and the Cretaceous and their relation to ultrabasic rocks. Ore Geol. Rev. 1987, 2, 359-404. [CrossRef]

2. Rosenberg, F. Geochemie und Mineralogie Lateritischer Nickel und Eisenerze in Lokris und auf Euboa, Griechenland, Unpublished. Ph.D. Thesis, University of Hamburg, Hamburg, Germany, 1984. (In German)

3. Andoniades, P.A.; Vgenopoulos, A. Study of the nickeliferous bauxitic laterite of the area N. Kokkino-Lokris. Metal. Miner. Ann. 1989, 65, 51-60.

4. Mposkos, E.; Perraki, T.; Kolokotroni, K. The Ni and Cr distribution in the mineralogical phases of the nickeliferous laterites from Evia Island. Miner. Wealth 1996, 101, 9-26. (In Greek)

5. Mposkos, E.; Orphanoudaki, A.; Perraki, T. The Ni distribution in the mineral phases of Greek Fe-Ni laterite deposits. In Proceedings of the 3rd Congress of Mineral Wealth, Athens, Greece, 22-24 November 2000; pp. 107-115.

6. Samouchos, M.; Godelitsas, A.; Nomikou, C.; Taxiarchou, M.; Tsakiridis, P.; Zavasnik, J.; Gamaletsos, P.; Apostolikas, A. New insights into nanomineralogy and geochemistry of Ni-laterite ores from central Greece. Chem. Erde 2018, 79, 268-279. [CrossRef]

7. Christidis, G.E.; Skarpelis, N. Clay mineralogy of the sedimentary iron nickel ore of Agios Ioannis, NE Boeotia: New data and implication for diagenetic modifications. Bull. Geol. Soc. Greece 2010, 43, 2553-2561. [CrossRef]

8. Eliopoulos, D.; Economou-Eliopoulos, M.; Apostolikas, A.; Golightly, J.P. Geochemical features of nickel-laterite deposits from the Balkan Peninsula and Gördes, Turkey: The genetic and environmental significance of arsenic. Ore Geol. Rev. 2012, 48, 413-427. [CrossRef]

9. Kalatha, S.; Perraki, M.; Economou-Eliopoulos, M. The origin of bastnaesite (La, Nd, Y) in the Nissi (Patitiria) bauxite-laterite deposit, Lokris, Greece. Minerals 2017, 7, 45. [CrossRef]

10. Christidis, G.E.; Mitsis, I. A new Ni-rich stevensite from the ophiolite complex of Othrys, central Greece. Clays Clay Miner. 2006, 54, 653-666. [CrossRef]

11. Mano, E.S.; Caner, L.; Petit, S.; Chaves, A.P.; Mexias, A.S. Mineralogical characterisation of Ni-bearing smectites from Niquelândia, Brazil. Clays Clay Miner. 2014, 62, 324-335. [CrossRef]

12. Fonteneau, L.; Caner, L.; Petit, S.; Juillot, F.; Ploquin, F.; Fritch, E. Swelling capacity of mixed talc-like/stevensite layers in white/green clay infillings ("deweylite" / "garnierite") from serpentine veins of faulted peridotites, New Caledonia. Am. Mineral. 2020, 105, 1536-1546. [CrossRef]

13. Wojdyr, M. A general-purpose peak fitting program. J. Appl. Cryst. 2010, 43, 1126-1128. [CrossRef]

14. Warr, L.N. Recommended abbreviations for the names of clay minerals and associated phases. Clay Miner. 2020, 55, 261-264. [CrossRef]

15. Warr, L.N. IMA-CNMNC approved mineral names. Mineral. Mag. 2021, 85, 291-320. [CrossRef]

16. Buatier, M.D.; Früh-Green, G.L.; Karpoff, A.M. Mechanisms of Mg-phyllosilicate formation in a hydrothermal system at a sedimented ridge (Middle Valley, Juan de Fuca). Contrib. Mineral. Petrol. 1995, 122, 134-151. [CrossRef]

17. Beaufort, D.; Baronnet, A.; Lanson, B.; Meunier, A. Corrensite: A single phase or mixed-layer phyllosilicate in the saponite-tochlorite conversion series? A case study of Sancerre-Couy deep drill hole (France). Am. Miner. 1999, 82, 109-124. [CrossRef]

18. Robinson, D.; Schmidt, S.T.; Santana de Zamora, A. Reaction pathways and reaction progress for the smectite-to-chlorite transformation: Evidence from hydrothermally altered metabasites. J. Metamorphic Geol. 2002, 20, 167-174. [CrossRef]

19. Ryan, P.C.; Hillier, S. Berthierine/chamosite, corrensite and discrete chlorite from evolved verdine and evaporate-associated facies in the Jurassic Sundance Formation, Wyoming. Am. Miner. 2002, 87, 1607-1615. [CrossRef]

20. Drits, V.A.; Ivanovskaya, T.A.; Sakharov, B.A.; Zviagyna, B.; Gor'kovam, N.V.; Pokrovskaya, E.V.; Savichev, A.T. Mixed-layers corrensite-chlorites and their formation mechanisms in the glauconic sandstones-clayed rocks (Riphean, Anabar uplift). Lithol. Miner. Res. 2011, 46, 566-593. [CrossRef]

21. Beaufort, D.; Rigault, C.; Billon, S.; Billault, V.; Inoue, A.; Inoue, S.; Patrier, P. Chlorite and chloritization processesthrough mixed-layer mineral series in temperature geological systems-A review. Clay Miner. 2015, 50, 497-523. [CrossRef] 